\title{
KONCEPTI POLICENTRIČNE UREDITVE SLOVENIJE
}

\author{
Vladimir Drozg \\ Univerza v Mariboru, Pedagoška fakulteta, Oddelek za geografijo, \\ Koroška cesta 160, SI-2000 Maribor \\ e-naslov: vlado.drozg@uni-mb.si \\ Izvirni znanstveni članek \\ COBISS 1.01
}

\section{Izvleček}

Besedilo obravnava koncepte policentričnega razvoja Slovenije, kakršni so bili zasnovani v treh planskih dokumentih od leta 1974 do 2004, hkrati pa izpostavlja nekatere vsebine, ki bi jih kazalo ponovno premisliti. To so: namen policentrizma, število regionalnih središč, število hierarhičnih nivojev in ukrepi za izvajanje koncepta.

Ključne besede: policentrizem, regionalni razvoj, Slovenija

\section{POLYCENTRICAL CONCEPTS OF SPATIAL DEVELOPMENT IN SLOVENIA}

\begin{abstract}
The paper deals with the polycentrical concepts of regional development of Slovenia as they were established in three documents of regional planning between 1974 and 2004. Three issues have been discussed more precisely: the purpose of polycentrism, the number of regional centers, the number of hierarchical levels and the mesures for implementation of the concepts.
\end{abstract}

Key words: polycentrism, regional development, Slovenia 


\section{OPREDELITEV POJMA IN NAMEN PRISPEVKA}

Policentrizemje koncept ureditve upravne enote in regionalnega razvoja, kjernastaja več središč s podobno stopnjo centralnosti oziroma s podobnimi upravnimi, socialnimi, izobraževalnimi, kulturnimi in drugimi negospodarskimi dejavnostmi. V Urbanističnem terminološkem slovarju iz leta 1975 je policentrizem definiran kot: »razvijanje več pomembnih središč« (: 189). Nanaša se na dekoncentracijo in hkrati koncentracijo dejavnosti; dekoncentracijo $\mathrm{v}$ smislu preprečevanja koncentracije v enem, običajno državnem središču in koncentracijo, $\mathrm{v}$ smislu preprečevanja disperzije oziroma podvajanja dejavnosti $\mathrm{v}$ številnih majhnih središčih. Vladimir Mušič v knjigi Urbanizem - bajke in resničnost, razume policentrizem kot »naravno nadaljevanje decentralizacije političnega odločanja s ... konotacijo decentralizirane koncentracije... «(Mušič 1980: 28). Policentrizem je korekcija centralizacije (gledano od zgoraj navzdol) in centralizacija hkrati (gledano od spodaj navzgor). V policentrično urejeni državi je del pristojnosti prenešenih na središča večjih upravnih enot (npr. regij, pokrajin, okrajev), hkrati pa so v teh središčih združene nekatere dejavnosti iz manjših naselij. Koncentracija dejavnosti $\mathrm{v}$ večjih mestih je naravni proces, zaradi katere se povečujejo regionalne razlike vseh vrst, pojavljajo se negativni učinki koncentracije prebivalstva in delovnih mest, obremenjevanja okolja, visokih cen nepremičnin ipd. Policentrizem je korektiv procesa centralizacije, s katerim skušamo negativne učinke omejiti. Ob tem je potrebno dodati, da razglabljanja o policentrizmu temeljijo bolj na teoretičnih predpostavkah in generaliziranih predstavah o učinkih dejavnosti $\mathrm{v}$ prostoru, kakor na empiričnih podatkih in preverjenih izkušnjah.

Ključne vsebine policentrične ureditve države so: regionalna središča in njihova zaledja, pristojnosti središč oziroma obseg funkcij na posameznem nivoju ter ukrepi za izvanjanje.

1. Število regionalnih središč govori o »širini« policentrične ureditve. Veliko število regionalnih središč ni racionalno iz vidika narodnega gospodarstva, ob premajhnem številu pa je okrnjena osnovna ideja - enakomeren gospodarski in socialni razvoj celotnega teritorija ter izboljšanje dostopnosti do storitev. Izbrati ustrezno število regionalnih središč je pravzaprav osrednji problem policentrične ureditve države.

2. Policentričnaureditev državeje običajnohierarhična, karpomeni, da so centralne dejavnosti razporejene ne le horizontalno, ampak tudi vertikalno. Vertikalna razdelitev pomeni prenos pristojnosti države na nižje upravne nivoje (npr. na občino). Pri policentrizmu ne gre le za delitev upravnih pristojnosti, slednje je samo en vidik policentričnega konceptanujen, vendar ne zadosten. Policentrizem pomeni določeno stopnjo politične, gospodarske in socialne avtonomije. Število nivojev je pomembno v toliko, ker je s tem povezan nabor funkcij (pristojnosti), ki bi jih naj posamezna središča obsegala. Posebej želimo povdariti, da gre pri policentrizmu za koncentracijo in dekoncentracijo dejavnosti hkrati. Zato morajo biti znana »regionalna« središča, ki prevzemajo del dejavnosti od mest višjega ranga in v katerih se koncentrirajo dejavnosti iz mest nižjega ranga, znana pa morajo biti tudi območja (regije oziroma upravne enote nižje ravni), za katerih prebivalce bodo »regionalna« središča te dejavnosti opravljala; policentrizem in regionalizem sta dve plati iste medalje. 
3. Ker je intenca policentrizma nasprotna spontanemu in samoregulativnemu razvoju, so za vzpostavljanje policentrične ureditve potrebni učinkoviti instrumenti, ki delujejo kot korektiv procesu centralizacije. Instrumenti za izvajanje so običajno v domeni države, saj je (bolje: naj bi bil) policentrizem del javnega interesa skupnosti.

Koncept policentrizma sloni na teoriji centralnih krajev, ki sta jo na slovenske razmere priredila Vladimir Kokole in Igor Vrišer. Osnova te teorije je spoznanje, da je razmestitev naselij v pokrajini posledica ekonomskih zakonitosti o prostorskem dometu oskrbnih in storitvenih dejavnosti. W. Christaller je odkril princip, zaradi katerega je naselij z majhnim številom oskrbnih dejavnosti veliko, naselij z velikim številom oskrbnih dejavnosti pa je malo. Gravitacijska območja prvih so zato majhna, gravitacijska območja drugih pa velika. Samo velikost gravitacijskih območij in opremljenost naselij z oskrbnimi funkcijami nista dovolj za oblikovanje koncepta regionalnega razvoja. Drugi temelj policentrizma zato predstavlja teorija razvojnih polov, ki jo je zasnoval Francois Perroux. Ta pravi, da se zaradi gospodarskega in socialnega razvoja mesta del pozitivnih učinkov prenaša tudi v zaledje oziroma v okolico mesta. Ustrezna razmestitev razvojnih polov tako prispeva $\mathrm{k}$ hitrejšemu in enakomernejšemu razvoju celotnega teritorija države.

Teorija centralnih krajev oziroma aplikacija te teorije, ki jo običajno imenujemo urbani sistem, se pogosto istoveti s konceptom policentričnega razvoja. Vendar temu ni tako. Urbani sistem prikazuje hierarhijo vseh naselij na obravnavanem območju in temelji na opremljenosti naselij z oskrbnimi in storitvenimi dejavnostmi. Je odraz dejanskega stanja. Policentrični koncept razvoja določenega območja pa pomeni izbor naselij, imenujmo jih "regionalna središča «, v katerih bodo skoncentrirane dejavnosti, pomembne za gospodarski in socialni razvoj kraja in njegovega zaledja. Je torej planska kategorija. Izbor regionalnih središč običajno obsega naselja iste stopnje centralnosti in istega položaja v urbanem sistemu, vendar to nikakor ni nujno. Primer: z namenom vzpodbuditi razvoj manj razvitega območja, pridobi določeno naselje status regionalnega središča, čeprav po trenutni opremljenosti do takega statusa ni upravičeno. Povedano drugače: urbani sistem je samo strokovna podlaga za policentrični koncept razvoja države; med strokovno podlago in konceptom pa je še niz strokovnih in političnih odločitev, po katerih se en dokument loči od drugega. V urbanem sistemu so mesta razvrščena po enem samem kriteriju (običajno po opremljenosti), v konceptu regionalnega razvoja pa po več med seboj komplementarnih kriterijih.

Kljub temu, da je policentrizem takorekoč temeljni koncept razvoja Slovenije, je po mnenju mnogih v vsebinskem pogledu precej nedorečen (Vrišer 1989: 12, Mušič 1980: 28). 40 let od nastanka te ideje, ni njegova vsebina nič bolj razdelana, kot je bila takrat. Zdi se, da služi predvsem kot metafora in kot podoba idealne ureditve Slovenije. Zaradi novih okoliščin je poanta policentrizma danes morda celo drugačna, kot je bila ob nastanku. Namen pričujočega prispevka je opozoriti na nekatere nedorečenosti koncepta in na vsebine, ki bi jih kazalo ponovno premisliti. 


\section{KRATEK ORIS KONCEPTOV POLICENTRIČNE UREDITVE SLOVENIJE}

Zasnova policentričnega razvoja je nastala okoli leta 1964, ob pripravi prvega regionalnega plana Republike Slovenije. V strokovnih gradivih za pripravo regionalnega plana je zapisana temeljna ideja koncepta, katerega namen je: »razvijanje centrov, ki bi bolj ali manj enakomerno razporejeni zagotavljali vsemu slovenskemu prebivalstvu enake razvojne in oskrbne možnosti« (Zasnova urbanizacije, 1974: 53). V drugem dokumentu je cilj naveden še natančneje: »... policentrizem kot temeljni cilj za skladen, hiter in stabilen socialni, ekonomski in prostorski razvoj vseh območij ..., to pomeni enake možnosti za delo, stanovanje, počitek, rekreacijo in družbeni položaj vsakega občana.« (Sinteza... 1977: 2, poglavje: Skupni interesi in cilji).

Takšno vsebinsko izhodišče je ustrezalo ekonomskim, socialnim in ideološkim razmeram takratne družbe. Izenačevanje razmer za bivanje in delo lahko razumemo kot obliko vzpostavljanja socialne in prostorske pravičnosti, enakosti in dostopnosti dobrin za vse prebivalce. Koncept je ustrezal tudi ideološkim (urejevalskim) predstavam takratnega časa, ko se je zdela zamisel o vzpostavljanju ustroja prostora veliko bolj realna, kot to razumemo danes. In za vzpostavljanje »novega« ustroja prostora je pri policentričnem razvoju Slovenije pravzaprav šlo. Z državnimi intervencijami in planskim razmeščanjem gospodarskih dejavnosti naj bi dosegli enakomerno gospodarsko in socialno razvitost vseh delov republike. Ideja policentrizma se tudi sklada $\mathrm{z}$ intervencijsko in socialne vlogo države, kakršna je nastajala $\mathrm{v}$ socialističnem družbenem sistemu.

Dodelavo tega koncepta, predvsem pa njegovo implementacijo, je zavrlo politično dogajanje v Jugoslaviji. Leta 1974 je bila sprejeta ustava SFRJ, s katero so bile občinam dodeljene velike pristojnosti. Postale so ne le upravne, temveč tudi gospodarske enote, zadolžene za gospodarski razvoj na območju. V občinski proračun se je stekal večji del davkov in prispevkov krajanov in gospodarskih organizacij, kar je ekonomski položaj občin zelo okrepilo. Predvsem občinska središča so se razvijala kot gospodarska središča, kar je $\mathrm{v}$ številnih primerih odstopalo od policentrično zasnovanega urbanega sistema. Namesto 5 oziroma 13 regionalnih središč, kolikor jih je bilo opredeljenih v prvem konceptu, se je razvijalo 64 središč, kolikor je bilo občin.

Leta 1986 je bil sprejet drugi planski dokument republike, Dolgoročni plan SRS za obdobje 1986 - 2000. Policentrizem je ostal temeljni koncept prostorskega razvoja, čeprav daje dikcija zapisa slutiti, da gre za nekoliko drugačno usmeritev: »... gospodarske dejavnosti se bodo razvijale $\mathrm{v}$ skladu $\mathrm{z}$ zasnovo policentričnega razvoja ob upoštevanju značilnosti posameznih regij« (Dolgoročni plan ..., 1986: 66). Bolj kot enakomerna razmestitev oskrbnih in storitvenih dejavnosti, je v ospredju gospodarska vloga regionalnih središč. »Dolgoročna usmeritev v ustreznejšo poselitev slovenskega prostora terja: ustvarjanje dolgoročnih razmer za ohranitev prebivalstva na posameznih depopulacijskih območjih z odpiranjem delovnih mest, $\mathrm{z}$ razvojem storitvenih in družbenih dejavnosti in z izgradnjo infrastrukturnega omrežja ter racionalno zaposlovanje, ki bo preprečilo pretirano koncentracijo prebivalstva v posameznih območjih« in dalje: "V skladu s konceptom policentričnega razvoja se bo še naprej krepila zaposlitvena in oskrbna vloga regionalnih središč.« (ibid: 67). Če je v prejšnjem dokumentu 
prevladal vidik disperzije dejavnosti, se zdi, da je v obravnavanem prevladal vidik zmerne koncentracije funkcij. Policentrizem še vedno ni pojmovan kot dekoncentracija uprave in družbenih dejavnosti, temveč kot sredstvo za razmeščanje gospodarskih dejavnosti.

Regionalna središča so v tem dokumentu opredeljena po dveh kriterijih - po številu delovnih mest in po stopnji opremljenosti s terciarnimi in kvartarnimi dejavnostmi, pri čemer poanta prve klasifikacije ni povsem jasna (vsaj ne v kontekstu policentričnega razvoja).

Leta 1991 je v Sloveniji prišlo do sprememb gospodarskega in političnega sistema. V začetnem obdobju tržnega gospodarstva je bila ideja policentrizma zapostavljena na račun centralizacije državnih ustanov v novi prestolnici in konsolidacije gospodarstva. Vendar proces centralizacije ni trajal dolgo, sredi 90-tih let so se znova okrepile težnje po decentralizaciji oziroma policentričnem razvoju Slovenije. Spremenili pa so se nekateri »robni pogoji«, zaradi katerih je policentrizem dobil drugačno vsebino:

- Najpomembnejša je sprememba gospodarskega sistema iz planskega v tržno gospodarstvo in gospodarske usmerjenosti iz družbe proizvodnje $\mathrm{v}$ družbo potrošnje. V tržnem gospodarstvu, kakršno se razvija v Sloveniji, ima država bistveno manjše možnosti usmerjanja regionalnega razvoja, kot v planskem gospodarstvu.

- $\quad$ Spremenil se je značaj prostorskega (regionalnega) planiranja, ki je v novih gospodarskih razmerah izgubilo nekdanjo usmerjevalno vlogo, okrepila pa se je regulativna vloga - gre za premik od vzpostavljanja ustroja prostora $\mathrm{k}$ upravljanju s prostorom.

- Zelo se je povečala mobilnost prebivalcev, kar pomeni, da so dejavnosti v mestih, dostopne večjemu številu ljudi. Spremenila se je tudi razmestitev prebivalcev - v okolici večjih mest prihaja do koncentracije, na delu podeželja pa do stagnacije oziroma upadanja števila prebivalcev.

Tudi v Strategiji prostorskega razvoja Slovenije je koncept policentrizma postavljen v osredje. Poanta policentrizma je izboljšanje dostopnosti do dobrin javnega pomena. \... Ti centri (regionalna središča, op. V.D.) omogočajo prebivalstvu udobno, cenovno ugodno, varno in okoljsko sprejemljivo dostopnost do javnih funkcij, delovnih mest, storitev in znanja.« (Strategija ... 2004: 9228, alineja 2). V ospredju niso več mesta kot proizvodna središča, temveč središča oskrbnih in storitvenih dejavnosti. »Središča nacionalnega in regionalnega pomena so najpomembnejša središča dejavnosti družbene infrastrukture, oskrbnih, storitvenih, upravnih in drugih dejavnosti ter najpomembnejša gospodarska območja in prometna vozlišča (ibid, alineja 9). Ta koncept policentričnega razvoja uvaja »dvostopenjsko omrežje naselij«, in sicer regionalna središča mednarodnega pomena in regionalna središča nacionalnega pomena. Takšna ločitev v dokumentu ni utemeljena in pojasnjena, predpostavljamo pa, da je posledica pričakovanega gospodarskega povezovanja znotraj Evropske unije.

V Strategiji prostorskega razvoja Slovenije so opredeljena »gravitacijska« območja regije središč mednarodnega pomena se imenujejo funkcijska območja (Strategija ... 2004: 9228, alineja 7), regije regionalnih središč nacionalnega pomena pa se imenujejo regionalna območja (ibid, alineja 6). 


\section{KLJUČNE ZNAČILNOSTI KONCEPTOV POLICENTRIČNEGA RAZVOJA}

\section{Število in izbor regionalnih središč}

Izbor regionalnih središč je bil vsakič opravljen na podlagi drugih, čeprav podobnih kriterijev. $\mathrm{V}$ prvi zasnovi je bila upoštevana velikost gravitacijskih območij in opremljenost krajev $\mathrm{s}$ centralnimi dejavnostmi. Naselja, katerih gravitacijska območja na mezo nivoju so skupaj »pokrila« celoten teritorij republike, so bila uvrščena med pomembnejša regionalna središča. Opremljenost naselij s centralnimi dejavnostmi je služila kot korektiv kriteriju velikosti gravitacijskega območja. Ker je bil osnovni cilj policentrizma omogočiti enakomeren razvoj vseh delov republike, so bila med regionalna razvojna središča uvrščena tudi naselja v manj razvitih pokrajinah (npr. Murska Sobota).

V drugem konceptu iz leta 1974 je bilo opredeljenih 11 središč, ki so bila izbrana glede na opremljenost s centralnimi dejavnostmi in glede na število delovnih mest oziroma njihov gospodarski pomen. Naseljem, ki so imela več centralnih dejavnosti in večje število delovnih mest je bil pripisan večji pomen v razvoju Slovenije.

Preglednica 1: Naselja, ki jih lahko pojmujemo kot regionalna središča

Table 1: Regional centres in different concepts

\begin{tabular}{|c|c|c|c|}
\hline & 1. koncept* & 2. koncept** & 3. koncept ${ }^{* * *}$ \\
\hline $\begin{array}{l}\text { Višji } \\
\text { nivo }\end{array}$ & $\begin{array}{l}\text { Ljubljana } \\
\text { Maribor } \\
\text { Celje } \\
\text { Novo Mesto } \\
\text { Koper }\end{array}$ & $\begin{array}{l}\text { Ljubljana } \\
\text { Maribor } \\
\text { Celje } \\
\text { Novo Mesto } \\
\text { Koper } \\
\text { Nova Gorica } \\
\end{array}$ & $\begin{array}{l}\text { Ljubljana } \\
\text { Maribor } \\
\text { Koper }\end{array}$ \\
\hline $\begin{array}{l}\text { Nižji } \\
\text { nivo }\end{array}$ & $\begin{array}{l}\text { Murska Sobota } \\
\text { Ptuj } \\
\text { Slovenj Gradec } \\
\text { Kranj } \\
\text { Jesenice-Bled-Radovljica } \\
\text { Zagorje-Trbovlje- } \\
\text { Hrastnik } \\
\text { Krško-Brežice } \\
\text { Nova Gorica }\end{array}$ & $\begin{array}{l}\text { Murska Sobota } \\
\text { Ptuj } \\
\text { Slovenj Gradec-Ravne- } \\
\text { Dravograd } \\
\text { Kranj } \\
\text { Jesenice-Bled-Radovljica }\end{array}$ & $\begin{array}{l}\text { Murska Sobota } \\
\text { Ptuj } \\
\text { Slovenj Gradec-Ravne- } \\
\text { Dravograd } \\
\text { Kranj } \\
\text { Jesenice -Radovljica } \\
\text { Zagorje-Trbovlje- } \\
\text { Hrastnik } \\
\text { Krško-Brežice-Sevnica } \\
\text { Nova Gorica } \\
\text { Celje } \\
\text { Velenje } \\
\text { Novo Mesto } \\
\text { Postojna }\end{array}$ \\
\hline
\end{tabular}

Vir: * Zasnova urbanizacije, karta: Razvojna središča in njihova vplivna območja (: 59)

** Dolgoročni plan SR Slovenije za obdobje 1986-2000, karta 1: Zasnova primarne rabe in poselitvenega sistema

*** Strategije prostorskega razvoja Slovenije, karta 4: Zasnova policentričnega urbanega sistema in razvoj širših mestnih območij (: 9231) 
$\mathrm{V}$ tretjem konceptu so bila regionalna središča izbrana glede na število prebivalcev. To je posredni kiterij, s katerim je kljub temu mogoče opredeliti najvplivnejša mesta, z največjim številom centralnih dejavnosti.

$\mathrm{V}$ dosedanjih konceptih policentrične zasnove razvoja Slovenije se je pojavljalo naslednje število regionalnih središč najvišje stopnje: v prvi zasnovi jih je bilo 13, v drugi 11, v tretji je opredeljenih 15 .

\section{Število nivojev in vrsta dejavnosti na posameznem nivoju policentrične ureditve države}

Dosedanji koncepti so bili zasnovani na različnem številu nivojev; v prvem konceptu so bilo opredeljeni 4, v drugem in tretjem pa 6. Bolj kot po številu nivojev, se koncepti razlikujejo po številu naselij na posameznem nivoju. Ker kategorije niso povsem primerljive, se moramo omejiti samo na naselja najvišjih nivojev. V 1. konceptu jih je 13, v 2. konceptu 11, v 3. pa kar 29. V vseh primerih, še najmanj v prvem, je opazna povezava z zasnovo urbanega sistema, ki je bil v zasnovan na 7 do 9 hierarhičnih stopnjah (po Vrišerju in Kokoletu), v kasnejši raziskavi pa je Vrišer število stopenj zmanjšal na 4.

Preglednica 2: Število hierarhičnih nivojev v posameznih konceptih (v oklepaju je število naselij na posameznem nivoju)

Table 2: The number of hierarchical levels in each concept (in brackets there is the number of settlements of each level)

\begin{tabular}{|l|l|l|}
\hline 1 koncept & 2. koncept & 3. koncept \\
\hline Druga urbana središča (33) & Lokalno središče & Lokalno sredičče \\
Druga pomembnejša & Pomembnejše lokalno središče & Pomembnejše lokalno središče \\
regionalna središča (8) & Središče občinskega & Središče medobčinskega \\
Pomembnejše regionalno & pomena (33) & pomena (20) \\
razvojno središče (4) & Središče ožjega regionalnega & Središče regionalnega \\
Republiško središče (1) & pomena (6) & pomena (14) \\
& Središče širšega regionalnega & Središče nacionalnega \\
& pomena (5) & pomena (12) \\
& Središče republiškega & Nacionalno središče \\
& pomena (1) & mednarodnega pomena (3) \\
\hline
\end{tabular}

Vir: isto kot Preglednica 1

Posebno vprašanje so dejavnosti, ki naj bi jih naselja posameznega nivoja opravljala. V vseh konceptih so za razvrščanje uporabljene iste dejavnosti, katere določajo tudi položaj naselij v urbanem sistemu.

\section{Ukrepi za izvajanje}

Kljub pomenu, s kakršnim je policentrizem v planskih dokumentih obravnavan, niso niti $\mathrm{v}$ zakonskih aktih, niti v strateških dokumentih opredeljena določila, kako koncept izvajati. Od prve zasnove se je zakonodaja iz področja urejanja prostora spremenila že tri krat, vendar 
v nobeni niso navedeni instrumenti za izvajanje. Slednje je presenetljivo toliko bolj, ker so v Sloveniji vidni nekateri elementi policentrične ureditve. Menimo, da je to posledica neformalnih instrumentov regionalne politike, najbrž tudi tako imenovanega vzporednega učinka (tudi »součinka«, nem. Mitnahme-Effekt), kar pomeni nekaj, kar bi se spremenilo ali izvedlo tudi brezukrepov regionalne politike (po Maier, Tödtling 2002: 185). Ocenjujemo, da je bila večina neformalnih instrumentov vzpostavljena v 70-tih letih. V mislih imamo regionalno členitev Slovenije za potrebe delovanja državne uprave, npr. izpostave Geodetske uprave, regionalni Zavodi za zdravstveno varstvo, upravne enote, Okrajna sodišča, statistične regije, Regionalne razvojne agencije (seznam regionalnih členitev Slovenije glej na medmrežju 1). Nepomembna tudi ni še vedno živa zgodovinska členitev Slovenije na Gorenjsko, Štajersko, Koroško, Dolenjsko, Notranjsko, Primorsko in Prekmurje, v okviru katerih nastajajo številna politična in civilna združenja. Tudi pri razdeljevanju sredstev državnega proračuna je regionalni ključ pogosto uporabljen.

\section{KLJUČNIM VSEBINAM KONCEPTA NA ROB}

Kot smo že omenili, koncept policentrizma ni dorečen, zato tudi posamezni deli koncepta niso povsem skladni med seboj. V kratkem historiatu smo skušali prikazati, da je že formulacija o namenu policentrizma zelo splošna, je bolj usmeritev, kakor razdelan sistem ciljev in ukrepov. Bistvena vprašanja so še brez odgovora. Med takšna sodi, kaj želimo s policentrizmom doseči in kako, s katerimi instrumenti. Odgovor je pomemben, ker je od njega odvisno število regionalnih središč, velikost regij, pa tudi število nivojev, nenazadnje tudi ukrepi za izvajanje. Iz pregleda prejšnjih konceptov je razvidno, da namen policentrizma ni bil v vseh obdobjih enak. V prvem konceptu je bila izpostavljena enakomerna razmestitev gospodarskih središč, $v$ drugem je bila v ospredju krepitev gospodarskih središč, v zadnjem konceptu pa je v ospredju razmeščanje oskrbnih in storitvenih dejavnosti, pri čemer ni povsem jasno, ali je osnovni cilj razmeščanje tistih storitvenih dejavnosti, ki sodijo k tako imenovani družbeni infrastrukturi (zdravstvo, šolstvo, uprava, kultura), ali tudi dejavnosti, s katerimi upravlja zasebni kapital in so prepuščene tržnim zakonitostim. Dosedanji namen policentrizma lahko povzamemo z naslednjimi besedami: vzpostavljanje pogojev za enakomernejši gospodarski in socialni razvoj vseh delov države in s tem zmanjšanje regionalnih razlik ter izboljšanje kakovosti bivalnih razmer $z$ enakomerno razmestitvijo delovnih mest in družbene infrastrukture. Omenili smo nove okoliščine, zaradi katerih so se spremenili pogoji za izvajanje policentrične ureditve države, pojavile pa so se še nove vsebine, ki v prejšnjem obdobju niso bile tako izrazite. Sodobni policentrizem pomeni tudi politično in upravno avtonomnost delov države, pa tudi razvijanje njihove regionalne identitete. Menimo, da je bolj izpostavljena tudi delitev med javnim in zasebnim interesom. Zato se policentrizem po našem mnenju nanaša na razmeščanje predvsem tistih dejavnosti, ki so v domeni države (javnega interesa) in ne dejavnosti, katerih delovanje urejajo tržni mehanizmi (oziroma zasebni interes). Namen policentrizma bi danes lahko formulirali nekako tako: vzpostavljanje približno enake dostopnosti do storitvenih dejavnosti in družbene infrastrukture za vse prebivalce Slovenije, omogočanje avtonomije odločanja in upravljanja posameznih delov države ter krepitev regionalne identitete. 
Če sprejmemo takšno definicijo policentrizma, potem kaže ponovno premisliti o ključnih vsebinah:

\section{Izbor (regionalnih) središč na nivoju države.}

Za izbor regionalnih središč je bistveno dvoje:

- opremljenost z dejavnostmi kvartarnega sektorja, v prvi vrsti upravo, nato še zdravstvom, šolstvom in kulturo. Mesta, ki imajo vse naštete funkcije regionalnega pomena (npr. regijsko bolnišnico, regijski muzej), tvorijo ogrodje policentrične ureditve Slovenije. Ta mesta so: Ljubljana, Maribor, Koper, Kranj, Celje in Nova Gorica (upoštevali smo: regionalno bolnišnico, muzej, gledališče ter visoko ali višješolske ustanove; Drozg 1999, dopolnjeno 2005). Nekoliko manj dejavnosti, vendar še vedno veliko, je v Novem Mestu, Murski Soboti, Brežicah, Idriji, Izoli, Jesenicah, Ptuju, Slovenj Gradcu in v Trbovljah.

- dostopnost do naselij, ki imajo največ kvartarih dejavnosti. Menimo, da je v družbi potrošnje in v dobi terciarizacije prav slednje eden od temeljnih pomenov za policentrični razvoj - omogočiti čim večjemu številu prebivalcev iz vseh delov države primeren dostop do oskrbnih in storitvenih dejavnosti ter do družbene infrastrukture. Če za izhodišče izbora regionalnih središč upoštevamo opremljenost naselij s centralnimi dejavnostmi regijskega pomena ter 30 minutno dostopnost se izkaže, da 6 mest z največjim številom centralnih dejavnosti ne pokrije celotnega teritorija države oziroma najbolj poseljenih območij. Za pokritost celotnega teritorija države s 30 minutno izohrono bi bilo potrebnih 16 regionalnih sredič, in sicer še: Novo Mesto, Murska Sobota, Ptuj, Slovenj Gradec, Brežice, Trbovlje, Postojna, Kočevje, Idrija in Tolmin. Za 50 minutno dostopnost do regionalnih središč pa bi bilo dovolj 8 središč (Ljubljana, Maribor, Celje, Koper, Kranj, Murska Sobota, Novo Mesto in Nova Gorica).

\section{Karta 1: Območja 50 minutne dostopnosti do regionalnih središč}

Map 1: The areas of 50 minutes accessability to regional centers

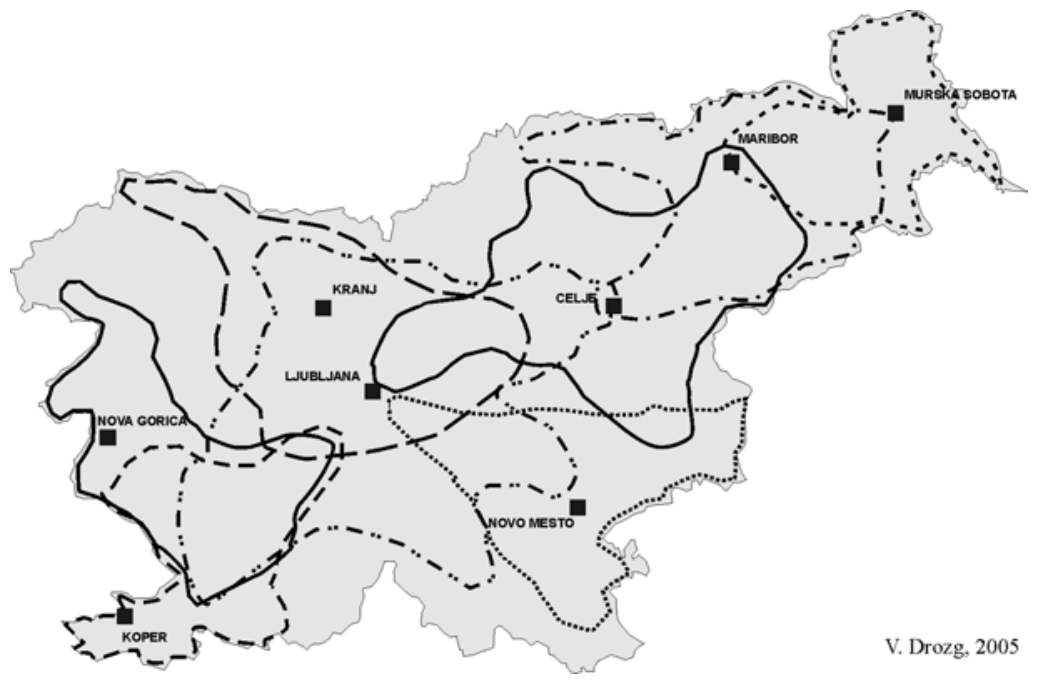




\section{2. Število hierarhičnih nivojev policentričnega koncepta.}

V dosedanjih konceptih so bila naselja razvrščena glede na vrsto in število dejavnosti (centralnih funkcij), pri čemer je bil nabor dejavnosti natančno določen in zato zelo statičen (kot primer glej: Uredba ..., 2004, Priloga 1, poglavje 2.5). Menimo da je ustrezneje, število nivojev prilagoditi pristojnostim, ki jih imajo naselja posameznega nivoja za upravljanje pripadajoče regije. Takšno stališče je blizu diskusijam, ki potekajo med pravnimi strokovnjaki o razdelitvi Slovenije na nove upravne enote, tako imenovane pokrajine. Večina pravnih strokovnjakov se zavzema za tri stopenjsko upravno ureditev, in sicer na državno, pokrajinsko in občinsko raven (Šmidovnik v Ribičič, 1998).

Dejavnosti družbene infrastrukture v Sloveniji (npr. uprava, bolnišnice, muzeji, šole) so večinoma že organizirane na treh nivojih: državnem (npr. institucije državne uprave, klinični center, narodni muzej, narodno gledališče, univerza), regijskem (medobčinski zavodi, regionalna bolnišnica, regionalna knjižnica, srednješolski center) in lokalnem (občina, bolnica-ambulanta, lokalna knjižnica, srednja šola); (glej medmrežje 1). Tri stopenjski sistem se zdi ustrezen, ker so razmerja med dejavnostmi na posameznem nivoju dokaj jasna. Tako lahko ločimo:

- $\quad$ središča državnega pomena: v njih so dejavnosti državnega pomena, npr. državna uprava, visokošolski zavodi, kulturne institucije državnega pomena

- $\quad$ središča regijskega pomena: v njih so dejavnosti, pomembne za delovanje regije

- $\quad$ središča lokalnega pomena, $v$ katerih so združene dejavnosti na nivoju občin

Večje število hiererhičnih nivojev pomeni bolj difierencirane pristojnosti središč, iz vidika regionalnega planiranja pa večjo diferenciranost dejavnosti določenega nivoja, kar lahko vzbuja vrsto vprašanj, tako vsebinskih, kot izvedbenih (npr. glede uresničevanja in nadziranja takšnega sistema). Opredeljevanje nivojev po pristojnostih je bolj v duhu policentrizma, ker poleg decentralizacije vsebuje tudi vidik centralizacije, kar je, kot smo že omenili, drugi pol policentrizma.

\section{Instrumenti za izvajanje policentričnega koncepta.}

$\mathrm{V}$ dosedanjih dokumentih instrumenti niso bili opredeljeni, tudi $\mathrm{v}$ pregledani literaturi $\mathrm{o}$ policentrizmu nismo zasledili konketnih predlogov. Instrumenti za izvajanje policentrizma so:

- $\quad$ prenos (decentralizacija) dela pristojnosti države na regije (pokrajine) oziroma regionalna središča

- $\quad$ prenos (koncentracija) nekaterih pristojnosti občin (občinskih središč) na nivo pokrajin (regionalnih središč)

- $\quad$ prioritetno reševanje prostorskih konfliktov v regionalnih središčih (npr. promet, okolje)

- koncentracija družbene infrastrukture državnega in regionalnega pomena $\mathrm{v}$ regionalnih središčih

- $\quad$ zagotavljanje površin za gospodarski in socialni razvoj regionalnih središč

Policentrična zasnova ni stvar samo prostorskih planov, temveč vseh dokumentov, ki imajo kakorkoli opraviti z razmeščanjem in vzpodbujanjem razvoja gospodarskih dejavnosti. 
V prvi vrsti bi morala koncept prevzeti strategija gospodarskega razvoja, za njo pa vse druge »strategije«, ki se nanašajo na razdeljevanje proračunskega denarja in razmeščanje družbene in tehnične infrastrukture $\mathrm{v}$ državi.

Pomembno je, da so tri ključne značilnosti policentrizma med seboj povezane $\mathrm{v}$ konsistentno celoto; število regionalnih središč in število regij je v tem kontekstu drugotnega pomena. Menimo, da koncept policentrične ureditve Slovenije iz leta 2004 še ni zadnji ...

\title{
Literatura
}

Blotevogel, H., 2002: Fortentwicklung des Zentrale-Orte-Konzepts. ARL, Hanover.

Dolgoročni plan SR Slovenije za obdobje od leta 1986 do leta 2000. 1986: Zavod SRS za družbeno planiranje, Ljubljana.

Drozg, V., 1999: Opredelitev naselij, upravičenih do statusa mesto. Služba za lokalno samoupravo RS, Ljubljana.

Maier, G., Tödtling, F., 2002: Regional- und Stadtökonomik. Springer, Dunaj.

Mušič, V., 1980: Urbanizem - bajke in resničnost. Cankarjeva založba, Ljubljana.

Pogačnik, A., 1992: Urejanje prostora in varstvo okolja. Mladinska knjiga, Ljubljana.

Ravbar, M., 2000: Omrežje naselij in prostorski razvoj Slovenije. Inštitut za geografijo, Ljubljana.

Ribičič, C., 1998: Regionalizem v Sloveniji. ČZ Uradni list RS, Ljubljana.

Sinteza (povzetki) strokovnih gradiv, ki zadevajo prostorski plan SR Slovenije. 1977, Zavod SR Slovenije za družbeno planiranje, Ljubljana.

Strategije prostorskega razvoja Slovenije. UL RS 76/2004.

Urbanistični terminološki slovar. 1975: Urbanistični inštitut SR Slovenije, Ljubljana.

Vrišer, I., Policentrizem v Sloveniji. IB 1989/štev. 5, str. 11 - 17.

Uredba o vsebini poročila o stanju na področju urejanja prostora ter minimalnih enotnih kazalnikih. UL RS 107/2004.

Zasnova urbanizacije. 1974: Regionalni prostorski plan za območje SR Slovenije. Zavod SR Slovenije za regionalno prostorsko planiranje, Ljubljana.

Medmrežje 1: www.stat.si / katalog

\section{POLYCENTRICAL CONCEPTS OF SPATIAL DEVELOPMENT IN SLOVENIA}

\begin{abstract}
Summary
Polycentrism is one of the elementary directions of spatial development in Slovenia. The concept was designed in the first spatial plan during the 1960s and later confirmed twice: first in 1986 in the long-term plan of Slovenia and later in 2004 in the spatial development strategy. The purpose of polycentrism was to create conditions for a more uniform economic and social development of all parts of the former republic as well as to provide a uniform
\end{abstract}


allocation of working places and social infrastructure. However, the concept to the most part remained unsaid. Regional centers, which should have taken over part of the country's competencies were not clearly defined, neither were instruments that should have been used for the execution of the concept.

Today we are confronted with different economic environment and a changed regional planning. The purpose of a polycentric arrangement is therefore different, too. We can understand it as a reestablishment of approximately the same access to services and social infrastructure, opportunity to enable autonomy of decision-making and management of certain administrative units and development of local identity. In sight of the latter, the following issues of polycentrism are important:

\section{Regional centers}

The most important issue for the selection of regional centers is good equipment with services from the quaternary sector, beginning with administration, followed by health services, education and culture. Towns with the largest number of regional functions are Ljubljana, Maribor, Koper, Kranj, Celje and Nova Gorica. Less services are available in Novo mesto, Murska Sobota, Brežice, Idrija, Izola, Jesenice, Ptuj, Slovenj Gradec and Trbovlje. The second criterion is access to regional centers. If we consider a 30-minute access we find out that we need 16 regional centers. 8 regional centers suffice for a 50-minute access.

\section{The number of hierarchical levels of a polycentric concept}

Earlier concepts classified settlements according to type and number of functions. We believe that it is better if one adjusts the number of levels to competencies, available in individual settlements of a certain level for management of appertaining region. This point of view is close to the proposal of legal experts who would like to see a government with three levels of hierarchy: namely the state, province and municipality.

\section{Instruments for execution of a polycentric concept}

Earlier documents did not define such instruments. The following would be needed:

- transfer of certain competencies from the state to the provinces

- transfer of certain competencies from the municipality to provinces

- $\quad$ priority of solving spatial conflicts in regional centers (e.g. traffic, environment)

- concentration of social infrastructure of governmental and regional importance in regional centers

- $\quad$ ensuring areas for economic and social development of regional centers 